\title{
KESIAPSIAGAAN MENGHADAPI BENCANA BERBASIS SEKOLAH
}

\author{
Oleh \\ Heri \& Muhammad Ridwan Caesar \\ heri1984@unfari.ac.id / caesar.fisip13@gmail.com \\ Dosen Program Studi Ilmu Administrasi Negara \\ Fakultas Ilmu Sosial dan Ilmu Politik Universitas Al-Ghifari
}

\begin{abstract}
Abstrak
Masalah dalam penelitian ini adalah belum optimalnya kesiapsiagaan masyarakat dalam menghadapi bencana berbasis sekolah di Kecamatan Lembang Kabupaten Bandung Barat. Padahal, Provinsi Jawa Barat termasuk Kabupaten Bandung Barat merupakan daerah dengan tingkat kerawanan terhadap bencana yang cukup tinggi. Hal ini disebabkan sesar aktif Lembang yang membentang sepanjang 22 Kilometer (Km) dari Maribaya, Cibodas hingga Cisarua di utara Kecamatan Padalarang Kabupaten Bandung Barat. Sesar aktif tergolong kepada sesar normal dan menimpan potensi ancaman gempa dengan kekuatan 6,7 SR. Sesar aktif Lembang pernah menyebabkan gempa bumi dalam beberapa tahun terakhir ini yaitu pada tahun 2003 dan 2011, serta menyebabkan bencana longsor pada tahun 2015 dan 2016. Tahapan riset yang dilakukan diantaranya dengan mengidentifikasi berbagai permasalahan terkait dengan tema, mengidentifikasi data kondisi geografis, data demografis, serta observasi, wawancara, studi dokumentasi dan diskusi kelompok terfokus. Adapun metode penelitian yang dilakukan adalah penelitian tindakan (action research) dengan pendekatan kualitatif. Hasil penelitian diharapkan menghasilkan model kesiapsiagaan menghadapi bencana berbasis sekolah. Hal ini menjadi penting mengingat dengan dengan kesiapsiagaan menghadapi bencana, dimungkinkan secara preventif untuk meminimalkan potensi kerugian yang lebih besar ketika bencana itu terjadi.
\end{abstract}

Kata Kunci: kesiapsiagaan, bencana, berbasis sekolah

\begin{abstract}
The problem in this research is not optimal the public preparedness in facing schoolbased disaster in West Bandung regency. In fact, West Java Province, including West Bandung Regency, is an area with a high level of vulnerability to disasters. This is due to Lembang's active fault stretching for 22 kilometers from Maribaya, Cibodas to Cisarua in the north of Padalarang District, West Bandung Regency. Active faults are classified as normal faults and save potential earthquake threats with a magnitude of 6.7 SR. Lembang active faults have caused earthquakes in the last few years in 2003 and 2011, and caused landslides in 2015 and 2016. The stages of research conducted included identifying various issues related to the theme, identifying geographical conditions data, demographic data, as well as observation, interviews, documentation studies and focus group discussions. The research method used is action research with a qualitative approach. The results of the study are expected to produce a school-based disaster preparedness model. This is important considering that with disaster
\end{abstract}


preparedness, it is preventive to minimize the potential for greater losses when a disaster occurs.

Keywords: preparedness, disaster, school based

\section{Pendahuluan}

Kepulauan Indonesia berada di garis khatulistiwa, secara tektonik terletak di empat lempeng kerak bumi yang aktif: lempeng Indo-Australia terletak di selatan yang relatif bergerak ke utara dan lepeng pasifik serta lempeng renik Philipina di bagian timur yang cenderung bergerak ke arahbarat dan keduanya menumpu dibawah lempeng asia tenggara yang merupakan bagian dari lempeng besar Eurasia. Kenyataan ini jarang terjadi di muka bumi, menurut Russel Miller (1990) dalam Engkon. K. Kertapati (2010) diperkirakan 100 tahun yang akan datang kawasan kepualan Indonesia akan ditubruk oleh lempeng Indo-Australia dan hanya akan menyisakan pulau Sumatera, Bangka dan beberapa pulau kecil lainnya. Pada umumnya di dunia ini benturan lempeng kerak bumi hanya melibatkan dua lempeng saja, tetapi di Indonesia melibatkan 4 lempeng sekaligus sehingga menjadi sangat rumit keadaan tektoniknya.

Menurut United Nation International Strategy fo Disaster Reduction (UNISDR) Indonesia berada pada peringkat ketiga paling rawan gempa di dunia. Hal ini penegasan bagi masyarakat Indonesia untuk lebih meningkatkan upaya penanggulangan bencana. Bencana gempa dan tsunami yang terjadi di Provinsi Aceh dan Nias pada tahun 2004 telah menyadarkan negara Indonesia untuk melakukan penanggulangan bencana secara komperehensif, maka sebagai respon terhadap hal tersebut pada tahun 2007 dilahirkan Undang-undang (UU) Nomor 24 tentang Penanggulangan Bencana sekaligus menjadi pondasi awal langkah penanggulangan bencana yang profesional di Indonesia.

Berdasarkan peta indeks kerawanan bencana yang dirilis oleh Badan Nasional Penanggulangan Bencana (BNPB) menunjukkan Provinsi Jawa Barat sebagai Provinsi dengan tingkat kerawanan bencana paling tinggi di Indonesia, mulai dari sebaran potensi bencana yang sangat beragam, jumlah penduduk dan kondisi geografisnya. Beraktivitas didaerah yang rawan bencana gempa adalah kenyataan yang harus dihadapi oleh masyarakat yang tinggal disekitar sesar aktif Lembang. Sesar aktif Lembang yang membentang sepanjang $22 \mathrm{~km}$ dari Maribaya, Cibodas hingga Cisarua 
di utara Kecamatan Padalarang Kabupaten Bandung Barat. Sesar aktif tergolong kepada sesar normal dan menimpan potensi ancaman gempa dengan kekuatan 6,7 SR.

Sesar aktif Lembang pernah menyebabkan gempa bumi dalam lima tahun terakhir ini yaitu pada tahun 2003 dan 2011. Pada tanggal 28 Agustus 2011 terjadi gempa di Kecamatan Cisarua Kabupaten Bandung Barat dengan kekuata 3,3 Skala Richter (SR) dengan kedalaman pusat gempa $10 \mathrm{Km}$. Gempa tersebut memang berkekuatan rendah namun menyebabkan kerusakan yang cukup parah pada beberapa rumah, hal ini menunjukkan bahwa sesar Lembang merupaka suatu ancaman/ bahaya yang nyata bagi masyarakat yang tinggal di kawasan sesar Lembang khusunya dan masyarakat yang tinggal di kawasan Bandung Raya (Kabupaten Bandung, Kabupaten Bandung Barat dan Kota Bandung) pada umumnya.

Berdasarkan publikasi ilmiah tesis mahasiswa Studi Sains Kebumian Institut Teknologi Bandung, Didik Wahju Widjaja menyatakan bahwa gempa bumi yang bersumber dari sesar aktif Lembang dapat mengakibatkan kerusakan tidak hanya untuk wilayah Lembang, namun juga berpotensi menyebabkan kerusakan untuk wilayah Kabupaten Bandung dan Kota Bandung. Gempa bumi tidak menjadi sebuah bencana jika tidak menyebabkan reruntuhan yang dapat mengakibatkan penderitaan bagi manusia. Gempa bumi tidak menghasilkan bahaya langsung bagi manusia karena gempa hanya merupakan getaran bumi, yang dapat membahayakan manusia jika gempa tersebut mengakibatkan kerusakan dan reruntuhan bangunan yang dapat menimpa manusia. Reruntuhan inilah yang mengakibatkan hilangnya nyawa dan penderitaan lain.

Masyarakat Indonesia sudah tidak terlalu awam dengan kejadian gempa bumi, tetapi usaha-usaha untuk mengurangi risiko bencana gempa belum menjadi budaya dalam kehidupan. Kegiatan pengurangan risiko bencana gempa dapat meminimalisir kerusakan, kerugian atau penderitaan-penderitan yang diakibatkan bencana gempa. Elemen masyarakat yang paling rentan dalam kejadian bencana adalah anak-anak, khususnya anak-anak dalam kesehariannya beraktivitas di sekolah. Dalam sehari ratarata anak-anak dapat menghabiskan waktunya selama 8 jam di sekolah, sehingga sekolah dapat dikategorikan sebagai tempat yang rawan bencana bagi anak-anak karena belum memiliki kegiatan pengurangan risiko bencana berbasis sekolah (PRBBS).

Undang-undang Nomor 24 tahun 2007 tentang Penanggulangan Bencana BAB V yang berbicara mengenai Hak Dan Kewajiban Masyarakat pada Pasal 26 berbunyi Setiap orang berhak Mendapatkan perlindungan sosial dan rasa aman, khususnya bagi 
kelompok masyarakat rentan bencana; Mendapatkan pendidikan, pelatihan, dan ketrampilan dalam penyelenggaraan penanggulangan bencana; Mendapatkan informasi secara tertulis dan/atau lisan tentang kebijakan penanggulangan bencana; Berperan serta dalam perencanaan, pengoperasian, dan pemeliharaan program penyediaan bantuan pelayanan kesehatan termasuk dukungan psikososial; Berpartisipasi dalam pengambilan keputusan terhadap kegiatan penanggulangan bencana, khususnya yang berkaitan dengan diri dan komunitasnya; dan Melakukan pengawasan sesuai dengan mekanisme yang diatur atas pelaksanaan penanggulangan bencana.

Fase pra bencana adalah fase penting dan sangat menentukan dalam setiap kejadian bencana yang terjadi. Manajemen pengurangan resiko bencana yang baik bisa meningkatkan kesiap-siagaaan masyarakat dalam menghadapi bencana yang berdampak pada berkurangnya resiko dan efek dari bencana yang terjadi, serta kemampuan masyarakat untuk melakukan pemulihan dan bangkit kembali setelah bencana berlalu.

Pada fase prabencana, anak sebenarnya memiliki potensi yang besar untuk bisa berperan dalam kegiatan pengurangan resiko bencana yang ada dilingkungannya, artinya bahwa sebelum terjadinya bencana anak-anak merupakan media efektif dalam mensosialisasikan upaya-upaya pencegahan dan penanggulangan bencana, anak-anak dengan kepolosan dan ketulusannya dapat dengan mudah menyerap semua informasi yang disampaikan apalagi bila informasi yang disampaikan dikemas dengan baik dan interaktif dengan menggunakan settting sekolah sebagai komunitasnya.

Belajar dari gempa dengan kekuatan 7,8 SR yang terjadi di Provinsi Shincuan, China pada tahun 2008 yang mengakibatkan ribuan siswa dan guru meninggal di sekolah. Sebagian besar dari 19.509 korban yang ditemukan di dalam kelas yang runtuh merupakan anak-anak atau siswa. Sementara itu sebanyak 124 ruang sekolah di empat Kecamatan Tarutung Kabupaten Tapanuli Utara rusak akibat gempa berkekuatan 5,5 Skala Richter yang melanda daerah itu pada tanggal 14 Juni 2011, beruntungnya gempa tersebut terjadi sebelum jam masuk sekolah sehingga tidak menimbulkan korban jiwa pada siswa sekolah. Isu pengurangan risiko bencana berbasis sekolah sudah di inisiasi oleh United Nation International Strategy fo Disaster Reduction (UN-ISDR) melalui program kampanye dunia pengurangan risiko bencana pada tahun 2006-2007.

Pada tanggal 2 Sepetember 2009 terjadi gempa bumi yang berpusat di Kabupaten Tasikmalaya dengan kekuatan 7,3 SR dan menyebabkan kerusakan hinggan ke Kota Bandung, Kabupaten Bandung dan Kabupaten Bandung Barat. Berdasarkan 
data yang dirilis oleh BNPB tentang jumlah rumah rusak berat akibar gempa di Kabupaten Bandung Barat Propinsi Jawa Barat menunjukkan bahwa tercatat 56 rumah rusak berat di Desa Langensari dan 12 rumah rusak berat di Desa Mekarwangi.

Data tersebut semakin menguatkan bahwa kegiatan pengurangan risiko bencana berbasis sekolah (PRBBS) adalah hal yang mutlak untuk dilaksanakan. Terutama untuk sekolah-sekolah yang berada tepat diatas sesar aktif seperti sekolah-sekolah yang berada di atas sesar aktif Lembang.

Untuk mewujudkan kesiapsiagaan komunitas sekolah dalam menghadapi potensi bencana gempa bumi maka Tim Peniliti tertarik untuk melakukan penyempurnaan model kesiapsiagaan gempa berbasis sekolah. Penyempurnaan ini ditempuh melalui penelitian dengan model penelitian tindakan partisipatif (parcipatory action resarch) sehingga anggota komunitas berpartisipasi secara aktif menemukenali, menggali serta mengevaluasi kondisi komunitas dalam kesiapsiagaan menghadapi bencana gempa. Kemudian dilakukan penyusunan rencana tindak bersama untuk diterapkan sesuai dengan elemen kesiapsiagaan yang belum dilaksanakan dengan harapan akan menyempurnakan model kesiapsiagaan menghadapi gempa berbasis sekolah.

\section{Tinjauan Pustaka}

Penelitian tentang Model Kesiapsiagaan Menghadapi Bencana Berbasis Sekolah di Kecamatan Lembang Kabupaten Bandung Barat mempunyai daya ungkit untuk penguatan sistem inovasi nasional, khususnya dalam hal penciptaan nilai tambah dan produktivitas ekonomi, publik dan akademik untuk peningkatan daya saing bangsa sebagaimana pendekatan kesisteman pengorganisasian penguatan inovasi nasional Dirjen Penguatan Inovasi Kemenristekdikti. Maksudnya adalah dengan penelitian ini akan memberikan dampak manfaat yakni terciptanya nilai tambah baik secara akademik maupun peningkatan produktivitas masyarakat sehingga mampu memiliki daya saing yang lebih baik dikarenakan masyarakat mempunyai pengetahuan sebagai hasil pemodelan dalam penelitian ini.

Menurut Badan Koordinasi Nasional Penanggulangan Bencana (2007: 3), bencana merupakan peristiwa atau rangkaian peristiwa yang mengancam dan menggangu kehidupan dan penghidupan masyarakat yang disebabkan, baik oleh faktor alam dan/atau faktor non alam maupun faktor manusia, sehingga mengakibatkan 
timbulnya korban jiwa manusia, kerusakan lingkungan, kerugian harta benda, dan dampak psikologis

Menurut Nurjanah, R. Sugiharto, Dede Kuswanda, Siswanto BP, Adikoesoemo (2012: 20), faktor-faktor yang dapat menyebabkan bencana, antara lain:

1. Faktor alam (natural disaster) karena fenomena alam dan tanpa ada campur tangan manusia.

2. Faktor non alam (non natural disaster) yaitu bukan karena fenomena alam dan juga bukan akibat perbuatan manusia.

3. Faktor sosial/manusia (man made disaster) yang murni akibat perbuatan manusia, misalnya konflik horisontal, konflik vertikal dan terorisme.

Secara umum faktor penyebab terjadinya bencana adalah karena adanya interaksi antara ancaman (hazard) dan kerentanan (vulnerability). Ancaman bencana menurut Undang-undang Nomor 24 Tahun 2007 adalah suatu kejadian atau peristiwa yang bisa menimbulkan bencana. Kerentanan terhadap dampak atau risiko bencana adalah kondisi atau karakteristik biologis, geografis, sosial, ekonomi, politikk, budaya dan teknologisuatu masyarakat di suatu wilayah untuk jangka waktu tertentu yang mengurangi kemampuan masyarakatv untuk mencegah, meredam, mencapai kesiapan, dan menanggapi dampak bahaya tertentu. Gempa bumi merupakan suatu gejala fisik atau kejadian alam yang umumnya ditandai dengan bergetar/berguncangnya bumi (Krishna S. Pribadi: 2008). Istilah gempa bumi terdapat beberapa macam apabila dilihat dari penyebabnya, antara lain gempa bumi tektonik, gempa vulkanik, gempa runtuhan, gempa imbasan dan gempa buatan.

Kesiapsiagaan adalah tindakan yang dilakukan dalam rangka mengantisipasi suatu bencana untuk memastikan bahwa tindakan yang dilakukan dapat dilaksanakan secara tepat dan efektif pada saat dan setelah terjadi bencana. Hal-hal yang dapat dilakukan umtuk meningkatkan kesiapsiagaan dalam menghadapi bencana, antara lain:

1. Pelatihan mengenai bagaimana menyelamatkan diri sendiri dan orang lain di sekitar kita saat terjadi bencana.

2. Koordinasi antara pihak-pihak terkait, siapa melakukan apa saat keadaan darurat, serta upaya evakuasi ke tempat yang aman.

3. Menyiapkan perlengakapan darurat saat terjadi bencana. 
4. Bagaimana memberikan pertolongan pertama pada orang yang terluka saat terjadi bencana.

5. Upaya-upaya yang dilakukan untuk pemulihan secara cepat, terutama pemulihan mental.

Kesiapsiagaan (preparedness) adalah setiap aktivitas sebelum terjadi bencana yang bertujuan untuk mengembangkan kapabilitas operasional dan memfasilitasi respon yang efektif ketika suatu bencana terjadi (Heru Susetyo, 2006: 1). UNISDR (Dheny Prasetyo dan Florensia Malau (ed), (2013: 7) menjelaskan kesiapsiagaan adalah upaya mengembangkan pengetahuan dan kapasitas pemerintah, lembaga, masyarakat dan perorangan dalam mengantisipasi, merespon dan pulih secara efektif dari dampakdampak peristiwa atau kondisi bencana yang mungkin ada, segera ada atau saat ini ada.

Beralih kepada pengertian bencana, John Twigg (Muhammad Aris Marfai, 2011:11) menyatakan, suatu kejadian akan disebut bencana apabila berdampak merugikan masyarakat serta masyarakat yang terkena dampak bencana tidak dapat menanganinya. Dhora Mathilde dan Natalie Pope Boyce (2008: 39) mendefinisikan gempa bumi sebagai suatu fenomena atau kejadian alam yang menimbulkan getaran pada lempeng atau permukaan bumi. Gempa bumi memiliki dampak berupa terganggunya aktifitas manusia baik di sektor pendidikan maupun ekonomi, tanah longsor, korban jiwa dan harta, kerusakan rumah dan bangunan, kebakaran, listrik padam, dan apabila gempa bumi terjadi di dalam laut, maka gempa bumi dapat berpotensi tsunami.

Pengertian Sekolah Sebagai Sebuah Komunitas menurut Judith A lewis (2003) sekolah adalah merupakan komunitas fungsional karena memiliki ciri-ciri yang sama dengan komunitas lainnya. Pengorganisasian komunitas atau masyarakat (community organizing/CO) pada dasarnya adalah serangkaian upaya membangun komunitas untuk mencapai taraf kehidupan yang lebih baik, lebih sejahtera, dan lebih adil dari sebelumnya dengan mengacu pada harkat dan martabat kemanusiaan seutuhnya. Intisari pemikiran dalam pengorganisasian komunitas antara lain.

1. Komunitas memiliki daya dan upaya untuk membangun kehidupannya sendiri.

2. Komunitas memiliki pengetahuan dan kearifan tersendiri dalam menjalani kehidupannya secara alami. 
3. Upaya pembangunan komunitas akan efektif apabila melibatkan secara aktif seluruh komponen komunitas sebagai pelaku sekaligus penikmat pembangunan.

4. Komunitas memiliki kemampuan membagi diri sedemikian rupa dalam peran pembangunan mereka.

Secara umum pengorganisasian komunitas didefinisikan sebagai proses membangun kekuatan dengan melibatkan konstituen sebanyak mungkin melalui proses menemu-kenali ancaman yang ada secara bersama-sama,menemu-kenali penyelesaianpenyelesaian yang diinginkan terhadap ancaman-ancaman yang ada; menemu-kenali orang dan struktur, birokrasi, perangkat yang ada agar proses penyelesaian yang dipilih menjadi mungkin dilakukan, menyusun sasaran yang harus dicapai, dan membangun sebuah institusi yang secara demokratis diawasi oleh seluruh konstituen sehingga mampu mengembangkan kapasitas untuk menangani ancaman dan menampung semua keinginan dan kekuatan konstituen yang ada. (Dave Beckwith dan Cristina Lopez, 1997: 2-4 dalam Puji Pujiono, dkk, 2009).

\section{Hasil Penelitian Dan Pembahasan}

Berdasarkan hasil observasi lapangan, sekolah yang terletak di Kecamatan Lembang tepatnya di Maribaya Timur atau dekat dengan puncak Sesar Aktif Lembang di bagian Timur (Gunung Batu) antara lain PAUD Desa Langensari, Madrasah Ibtidaiyah Negeri (MIN) Nyampai, SMPN 2 dan SMPN 6 Lembang, SMP dan SMA Mekarwangi, kesemua sekolah tersebut terletak di Maribaya Timur Kecamatan Lembang Kabupaten Bandung Barat.

Berdasarakan observasi tersebut, didapatkan informasi bahwa untuk memenuhi kebutuhan komunitas sekolah dalam penyelengaraan pengurangan risiko bencana gempa berbasis sekolah tersebut, telah dilakukan upaya untuk mengurangi risiko bencana melalui program Sekolah Siaga Gempa di Kawasan Maribaya Timur Kecamatan Lembang Kabupaten Bandung Barat.

Program ini dilaksanakan secara partisipatif bersama unsur-unsur komunitas sekolah PAUD Desa Langensari, MIN Nyampai, SMPN 2 dan SMPN 6 Lembang, SMP dan SMA Mekarwangi oleh Lembaga Swadaya Masyarakat (LSM) SBSM Indonesia bersama lembaga Amal Dompet Dhuafa Jawa Barat serta melibatkan pihakpihak yang terkait dengan Penanggulangan Bencana di Provinsi Jawa Barat yang dilaksanakan pada bulan Agustus hingga Desember 2013. 
Melalui kegiatan tersebut telah dilaksanakan upaya pengurangan risiko bencana gempa berbasis sekolah. Program ini bertujuan untuk membangun kesiapsiagaan komunitas sekolah dalam menghadapi ancaman bencana gempa bumi. Tahapan kesipasiagaan yang telah dilaksanakan meliputi; penilaian risiko bencana, pembuatan peta kawasan risiko bencana gempa, penentuan jalur evakuasi dan pemasangan ramburambu evakuasi, membangun sistem informasi peringatan dini, pendidikan dan pelatihan kebencanaan.

Sementara tahapan kesipasiagaan yang belum dilaksanakan adalah menyusun rencana kontijensi, melakukan koordinasi internal dan eksternal, mobilisasi sumber, menyusun mekanisme respon, dan melakukan gladi/simulasi rutin. Namun hal tersebut tidak dilaksanakan secara berkelanjutan.

\section{Peran Badan Penanggulangan Bencana Daerah Kabupaten Bandung Barat}

Leading sector dalam penanggulangan bencana, di sekolah maupun di luar sekolah adalah melalui optimalisasi peran dan fungsi badan penanggulangan bencana daerah. Badan Penanggulangan Bencana Daerah Kabupaten Bandung Barat tidak terlepas dari kondisi lingkungan internal dan eksternal serta kedudukan, tugas pokok dan fungsinya yang tidak terpisahkan dari visi dan misi Kepala Daerah dan Wakil Kepala Daerah Terpilih. Berdasarkan hal tersebut, maka pernyataan visi Badan Penanggulangan Bencana Daerah Kabupaten Bandung Barat adalah : -Terwujudnya Bandung Barat Yang Cermat dan Tangguh Dalam Menghadapi Bencana. Adapun misinya adalah:

1. Meningkatnya Pelayanan Administrasi Perkantoran dan Kapasitas Aparatur;

2. Terwujudnya perlindungan Masyarakat Kabupaten Barat dari ancaman bencana melalui pengurangan resiko;

3. Terselenggaranya Penanggulangan Bencana secara Terpadu dan Terkoordinasi;

4. Terwujudnya sinergitas Peran Pemerintah, Masyarakat dan Dunia Usaha dalam Penanggulangan Bencana; dan

5. Terbangunnya Sistem Informasi Kebencanaan bagi Publik.

Strategi - Strategi untuk mewujudkan Visi dan Misi yang telah ditetapkan dengan memperhatikan RPJMD Kabupaten Bandung Barat tahun 2013-2018 sebagai berikut: 
1. Menindaklanjuti struktur organisasi BPBD dan uraian tugas pokok dan fungsi pada Sekretariat dan masing-masing Bidang (Job Description), serta sosialisasi kepada aparat.

2. Menerapkan dan mengembangkan prinsip Paradigma Pengurangan Resiko Bencana dalam usaha penanggulangan bencana, Akuntabilitas Pelayanan Prima dan Akuntabilitas Publik dalam pelaksanaan tugas pemerintahan dan tugas penanggulangan bencana.

3. Meningkatkan peran serta masyarakat, dunia usaha dalam usaha penanggulangan bencana, memberikan pelayanan yang optimal dalam penanggulangan bencana mulai dari tahapan pra-bencana, tanggap darurat dan pasca bencana.

4. Mengembangkan kerjasama lintas program, lintas SKPD, bantuan teknis dengan instansi vertikal, horisontal dan non instansi dalam pelaksanaan tugas pokok pemerintahan dan penanggulangan bencana.

5. Menyusun, mengembangkan dan melaksanakan program penanggulangan bencana berdasarkan rencana stratejik yang terkoordinasi, sinkronisasi dan tepat sasaran.

6. Menyediaan sarana pendukung yang optimal seperti kendaraan operasional dan penyediaan peralatan berat yang memadai untuk penanggulangan bencana

7. Penambahan tenaga Sumber Daya Manusia untuk Pelaksana Administrasi, Satuan Tugas, Tim DaLA (Damage and Lost Asessment), dan Relawan Penanggulangan Bencana;

8. Mengembangkan kebijakan yang mengatur program penanggulangan bencana,. Sosiasilsasi, simulasi, pendidikan dan pelatihan penanggulangan bencana mulai pada tahapan pra-bencana, tanggap darurat dan pasca bencana; dan

9. Tersusun dan diterapkannya Peraturan Daerah, Peraturan Bupati, keputusan Kepala BPBD yang berhubungan dengan program penanggulangan bencana, serta informasi yang luas kepada masyarakat akan peraturan kebencanan tersebut agar masyarakat dapat mengerti dan memahami apa yang menjadi tanggung jawabnya terhadap upaya penanggulangan bencana dan bagaimana upaya pencegahan, mitigasi, dan pengurangan resiko bencana.

Arah kebijakan dalam upaya meningkatkan penyelenggaraan pemerintahan yang bersih dan akuntabel sesuai tugas dan fungsi Badan Penanggulangan Bencana Daerah Kabupaten Bandung Barat pada program Penanggulangan Bencana di Kabupaten Bandung Barat, beberapa kebijakan antara lain: 
1. Meningkatkan kualitas dan kuantitas SDM para penyelenggara penanggulangan bencana di daerah dan didukung sarana prasarana penanggulangan bencana yang memadai;

2. Mengoptimalkan bimbingan, pendidikan dan pelatihan, pembinaan teknis kegiatan simulasi penanggulanan bencana, secara profesional terhadap berbagai program/ kegiatan penanggulangan bencana;

3. Meningkatkan kualitas pelayanan masyarakat melalui program Reaksi Cepat pemantauan/pengawasan terhadap kejadian bencana dan upaya penanggulangan; dan

4. Meningkatkan peran serta masyarakat dan dunia usaha, dalam upaya pemanggulangan bencana.

Hasil wawancara dengan Kepala Sub Bagian Kepegawaian dan Umum, Badan Penanggulangan Bencana Daerah (BPBD) Kabupaten Bandung Barat, Bapak Nur Sigit, yang peneliti temui pada 28 Mei 2018, didapatkan informasi bahwa dalam menjalankan tugas pokok, fungsi serta berbagai strategi di atas, sejauh ini masih terdapat beberapa kendala, diantaranya kendala pendanaan.

Program-program yang dilaksanakan BPBD Kabupaten Bandung Barat menyangkut upaya membangun kesiapsiagaan menghadapi bencana berbasis sekolah sudah dilaksanakan, meskipun masih dalam lingkup terbatas. Contoh program yang dilaksanakan adalah dengan adanya pelatihan manajemen bencana bagi guru-guru atau kepala sekolah di Kabupaten Bandung Barat.

Program ini rutin dilaksanakan setiap tahun, dengan rata-rata peserta 50 orang setiap angkatan per tahun. BPBD Kabupaten Bandung Barat menampik akan makna prioritas pelatihan manajemen bencana berbasis sekolah, tetapi dibatasi oleh kemampuan anggaran yang tersedia. Namun demikian, peran serta pihak sekolah dalam menyelenggarakan berbagai pelatihan kesiapsiagaan bencana dibuka lebar oleh pihak BNPB Kabupaten Bandung Barat.

Terkait dengan posisi kesiapsiagaan bencana berbasis sekolah dalam kurikulum 2013 di tingkat SD, SMP, serta SMA di Kabupaten Bandung Barat, narasumber juga memberikan informasi bahwa saat ini kurikulum kesiapsiagaan bencana masih sebatas ekstrakurikuler, tidak masuk ke kurikulum inti. Hal ini difahami sebagai langkah baik meskipun menyadari bahwa dikarenakan masih bersifat ekstra kurikuler, bukan berarti tidak penting dan tidak prioritas, namun difahami sebagai upaya untuk lebih memberikan ruang bagi pengetahuan yang lain yang lebih substansial. 
Sejauh ini upaya untuk membangun kesiapsiagaan berbasis sekolah di Bandung Barat bersifat ekstrakurikuler, biasanya disatukan dengan kegiatan kepanduan/pramuka. Dengan kegiatan seperti itu pun, sudah berjalan baik dan memberikan pemahaman akan pentingnya kesiapsiagaan menghadapi bencana berbasis sekolah.

Dalam tatararan koordinatif, kesiapsiagaan menghadapi bencana berbasis sekolah di Kabupaten Bandung Barat sejauh ini belum dilaksanakan koordinasi antar organisasi. Dalam artian BPDB Kabupaten Bandung Barat masih berjalan sebatas melaksanakan program mandiri instansi BPBD Kabupaten Bandung Barat. Belum dilaksanakan koordinasi dengan Dinas Pendidikan Kabupaten Bandung Barat yang menjadi leading sector pendidikan jenjang SD dan SMP.

Selain melibatkan pihak sekolah, BPBD Kabupaten Bandung Barat pun melakukan berbagai upaya kesiapsiagaan menghadapi bencana berbasis masyarakat. Informasi yang didapatkan peneliti dari Kepala Sub Bagian Kepegawaian dan Umum pada 28 Maret 2018, BPDB Kabupaten Bandung Barat telah membentuk desa siaga bencana. Sampai dengan Mei 2018, sudah ada 1 desa siaga bencana, yakni Desa Cikahuripan Kecamatan Lembang Kabupaten Bandung Barat.

Desa siaga bencana ini sebagai upaya untuk mensosialisasikan kesiapsiagaan menghadapi bencana. Serta diharapkan semakin banyak agen-agen sosialisasi kesiapsiagaan menghadapi bencana berbasis masyarakat dan komunitas, sehingga dapat diminimalisasi resiko bencana.

\section{Manajemen Bencana di Sekolah}

Kementerian Pendidikan dan Kebudayaan melalui Biro Perencanaan dan Kerjasama Luar Negeri, bekerjasama dengan UNICEF telah mengeluarkan modul mengenai pendidikan dan penanggulangan resiko bencana, yang terdiri dari Modul 1 Pilar 1: Fasilitas Sekolah Aman; Modul 2 - Pilar 2: Manajemen Bencana di Sekolah; serta Modul 3 - Pilar 3: Pendidikan Pencegahan dan Pengurangan Risiko Bencana.

Dalam ketiga modul ini, yang dimaksud dengan sekolah adalah sekolah yang berada di bawah naungan Kementerian Pendidikan dan Kebudayaan serta madrasah yang berada di bawah naungan Kementerian Agama. Penyusunan modul-modul referensi ini merupakan hasil kerjasama antara Biro Perencanaan dan Kerjasama Luar Negeri dengan UNICEF Indonesia dalam Program Pengurangan Risiko Bencana yang 
bertujuan untuk membangun masyarakat yang aman dari ancaman bencana melalui berbagai upaya pengurangan risiko bencana.

Manajemen Bencana di Sekolah merupakan proses pengkajian yang kemudian diikuti oleh perencanaan terhadap perlindungan fisik, perencanaan pengembangan kapasitas dalam melakukan respon/ tanggap darurat, dan perencanaan kesinambungan pendidikan, di tingkat sekolah masing-masing sampai dengan otoritas pendidikan di semua tingkatan, baik kabupaten/ kota, provinsi hingga nasional.

Manajemen Bencana di Sekolah ditentukan melalui pihak-pihak berwenang di sektor pendidikan tingkat nasional, provinsi, kabupaten/ kota dan di tingkat komunitas sekolah (termasuk peserta didik dan orang tua peserta didik), bekerja sama dengan mitra di bidang manajemen bencana, untuk menjaga lingkungan belajar yang aman serta merencanakan kesinambungan pendidikan pendidikan baik di masa tidak ada bencana maupun di saat terjadi bencana, sesuai dengan standar internasional.

Sejalan dengan semangat untuk melindungi hak-hak anak atas perlindungan, keamanan dan kelangsungan hidup dan juga hak untuk mendapatkan pendidikan dasar yang berkualitas dan berkesinambungan, Kementerian Pendidikan dan Kebudayaan bermaksud untuk dapat menyebarkan pengetahuan mengenai pengurangan risiko bencana berikut fasilitas sekolah yang aman dan manajemen bencana di sekolah melalui guru maupun fasilitator, salah satunya dengan menyusun modul-modul yang dapat menjadi referensi para guru.

Langkah yang dilakukan diantaranya adalah dengan memetakan Peraturan Kepala Badan Nasional Penanggulangan Bencana Nomor 4 tahun 2012 tentang Pedoman Penerapan Sekolah/Madrasah Aman Bencana terhadap Kerangka Kerja Sekolah Aman yang Komprehensif, di mana Kerangka Kerja ini dengan tiga pilarnya sudah disepakati oleh dunia internasional, khususnya UNISDR sebagai Badan PBB bidang Pengurangan Risiko Bencana.

\section{Simpulan}

Kesiapsiagaan menghadapi Bencana berbasis sekolah di Kabupaten Bandung Barat sejauh ini dilaksanakan secara mandiri melalui program-program pelatihan, seminar, dan kegiatan lainnya oleh Badan Penanggulangan Bencana Daerah Kabupaten Bandung Barat. Belum dilaksankan koordinasi antar organisasi BPBD Kabupaten Bandung Barat dengan Dinas Pendidikan Kabupaten Bandung Barat, sehingga 
anggaran dan program yang dijalankan masih bersifat program mandiri institusi BPBD Kabupaten Bandung Barat.

Program yang sudah dilaksanakan bersifat rutin tahunan, yang dapat menyentuh 50 orang peserta per tahun. Peserta terdiri dari kepala sekolah dan guru, belum menyentuh secara esensial kepada komunitas sekolah, termasuk belum menyentuh peserta siswa dari sekolah yang ada di Kabupaten Bandung Barat. Namun demikian, dari aspek kesiapsiagaan berbasis masyarakat, sudah dibentuk desa siaga bencana, yakni Desa Cikahuripan Kecamatan Lembang Kabupaten Bandung Barat.

\section{DAFTAR PUSTAKA}

Abarquez, Imelda, Murshed, Zubair. (2004). Community-Based Disaster Risk Management. Field Practitioners Handbook. Asian Disaster Preparedness Center (ADPC), P.O. Box 4, Klong Luang, Pathumthani 12120, Thailand

Adimihardja (dkk). 2003. Participatory Research Appraisal dalam Pelaksanaan Pengabdian Kepada Masyarakat. Bandung : Humaniora

Affeltrenger, Bastian dkk. (2007). Hidup Akrab dengan Bencana. Sebuah Tinjauan Global tentang Inisiatif-inisisatif Pengurangan Bencana. Jakarta. MPBI

Affeltranger (et.al.) 2006. Living With Risk, A Global Review Of Disaster Reduction Initiatives. (Diterjemahkan oleh Theresia Wuryantari). Jakarta : MPBI

Alih Bahasa Drs. Chatib MA, Aji Wibowo Dkk. Technique And Guidelines For Social Work Practice (Bradfor, W Sheaford, Charles $R$ Horejsi, \& Gloria A Horejsi) Part IV : Chapter 10-14. (2006). Departemen Sosial RI. Badan Pendidikan dan Penelitian Pusat pendidikan dan Pelatihan Kesejahteraan Sosial.

Ali Soehatman. (2010). Pedoman Praktik Manajemen Bencana. Jakarta : Dian Rakyat

Carter WN. 1991. Disaster Management. A disaster Manager's Handbook. National Library of The Philiphines CIP Data. Asian Development Bank.

Chaskin Robert. J (et al) 2001. Building capacity community. New York. Aldine de Gruyter

Edi Suharto, (dkk), 2011. Pendidikan dan Praktik Pekerjaan Sosial di Indonesia dan Malaysia. Cetakan pertama. Yogyakarta : Samudera Biru.

- (2010). Cet.4. Membangun Masyarakat Memberdayakan Rakyat. Kajian strategis Pembangunan Kesejahteraan Sosial dan Pekerjaan Sosial. Bandung : PT. Refika Aditama

Isbandi. R. Adi (2008). Intervensi Komunitas Pengembangan Masyarakat sebagai upaya Pemberdayaan Masyarakat. Jakarta : PT.Raja Grafindo Persada 
Ife, Jim. Tesoriero, Frank. (2008). Community Development. Alternatif Pengembangan Masyarakat di Era Globalisasi. Jogjakarta. Pustaka Pelajar.

IDEP (2007), Panduang Penanggulangan Bencana Berbasis Masyarakat, seri Gempa Bumi. Bali : Yayasan IDEP

Jonatan Lassa, dkk (2009). Pengelolaan Risiko Bencana Berbasis Komunitas (PRBBK). Jakarta : PT. Grasindo.

Kertapati, Engkon K. (2006). Aktivitas Gempabumi di Indonesia: Perspektif Regional Pada Karakteristik Gempabumi Merusak. Bandung: Pusat Survei Geologi

Kirst-Ashman, Karen.K, Hull, Jr, Grafton.H. (2006). Understanding Generalis Practice. Thomson Brooks/Cole.

Moleong, Lexy.J. (2010). Cet.28. Metodologi Penelitian Kualitatif. Edisi Revisi. Bandung : PT. Remaja Rosdakarya.

Morris, Teresa. (2006). Methods Research Social Work. Four Alternative Paradigms. Sage Publication. Thousand Oak. London. New Delhi.

Nurjanah, dkk (2012). Manajemen Bencana. Bandung : Alfabeta.

Puji Pujiono, (ed). (2006). Kampanye Dunia Pengurangan Bencana: Pengurangan Risiko Bencana Dimulai di Sekolah. Jakarta: Masyarakat Penanggulangan Bencana Indonesia (MPBI)

Queralt, Magaly. The Social Environment And Human Behavior A Diversity Perspective. (1996). A. Simon \& Schuster Company Needham Heightt Mass.

Syarif Muhidin. (2011). Perencanaan Sosial. Bandung : STKSpress Bandung

Streeter, Calvin.L, Murty, Susan.A. (1996). Research on Social Work Disaster. The Hayworth Press, Inc.New York.London

Sugiyono. (2011). Cet.13. Metode Penelitian Kuantitatif, Kualitatif dan Research And Development $(R \& D)$. Bandung : Alfabeta.

Syafrezani, Sampaguita. (2010). Tanggap Bencana Gempa Bumi. Bandung: Angkasa

Streeter, Calvin.L, Murty, Susan.A. (1996). Research on Social Work Disaster. The Hayworth Press, Inc.New York.London

Ulber Silalahi, (2006), Metode Penelitian Sosial; Unpar Press; Bandung.

Tukino dan Suhendar (ed). (2009). Strategi Pengurangan Risiko Bencana. Bandung: STKS Press Bandung 
UNISDR (United Nation International Strategy Disaster Reduction). (2009). Terminologi Pengurangan Risiko Bencana. Indonesia. Asian Disaster Reduction Response Network (ADRRN)

Sumber lain :

Analisa Perkembangan Statistik Ketenagakerjaan. Laporan Sosial Indonesia . (2007). Badan Pusat Statistisk. 